\author{
高密度ポリエチレン (HDPE)の \\ ハイドラフィルム押出しに関する研究* \\ (静水圧押出加工時に発生する不安定現象の抑制について)
}

\author{
山岸裕**, 袴田正之茾* \\ 中山登史男****, 并上信 雄 ${ }^{* * * *}$
}

\title{
The Hydrafilm Extrusion of High-Density Polyethylene (Suppression of Instability in Hydrostatic Extrusion)
}

\author{
by Yutaka YAMAGISHI, Masayuki HAKAMADA, \\ Toshio NAKAYAMA, and Nobuo INOUE
}

\begin{abstract}
The hydrafilm extrusion of high-density polyethylene (HDPE) is investigated and its behavior is compared with that of pure hydrostatic extrusion at extrusion ratios up to 11 and temperatures up to $100^{\circ} \mathrm{C}$. Because of the use of a minimum amount of oil as lubricant and pressure-transmitting medium in hydrafilm extrusion, a serious problem of instability or stick-slip phenomena in the polymer extrusion was experimentally proved to be minimized. Also studied was the effect of the extrusion rate, which became more notable with the increase of the extrusion ratio. Billet temperature rise was found to affect the extrusion behavior to a great extent. The range of the extrusion rate for stable extrusion is delineated for a given value of the extrusion ratio.
\end{abstract}

Key Words: Plasticity, Forming, High-Density Polyethylene, Hydrostatic Extrusion, Stick-Slips

\section{1. 緒言}

高分子材料は金属材料と比較し軽量性・防振性など の面から非常に有利であるため近年，機械部品の材料 として注目されその応用も多岐にわたり研究されてい る. 現在その成形法としては溶融成形が一般的である が, その生産性・材料強度などを考虑すると高分子材 料の塑性加工は今後の有望な研究課題と言える.中で も固相状態での静水圧押出加工に上る引張強度・弾性 保数の向上などその物理的・機械的性質の向上が報告 されている(1).さらにその特長として高圧の液体によ る強制润滑効果が生じ従来の押出加工法に比べ低い押 出圧力での高速加工が可能となる点などが挙げられる が, その反面圧力媒体の圧縮性に起因寸る急激な圧力 降下ゃスティックスリップなどの発生が見ら机る。本 報ではこの種の動的不安定現象の防止を目的として八 イドラフィルム押出法を採用し高密度ポリエチレン (HDPE) の押出加工を行い，その挙動㧍よび特性を調

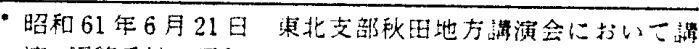
演, 源稿受付昭和60华12月27日.

“学生員，東京理科大学大学院 162 東宗都新宿区神楽坂 1-3).

…正員，(株)小亲製作所（正108 来京都港区高輪 4-8-3）。

…正員, 東京理科大学工学部
}

べ従来の静水圧押出しとの比較検討を行った。

\section{2. 実験 方 法}

$2 \cdot 1$ 押出装置本体押出装置本体は図 1 に示す ようなピストンーシリンダ方式の圧力容器を用いてい る.コンテナは 50 tf 油圧万能試験に取付けテーブル の上昇によりステムをコンテナ内に押し込み圧力媒体 を加圧する。さらに予加熱を行う押出しにはコンテナ 外壁に巻いたバンドヒータ $(100 \mathrm{~V} \times 1 \mathrm{~kW} 2$ pieces $) を$

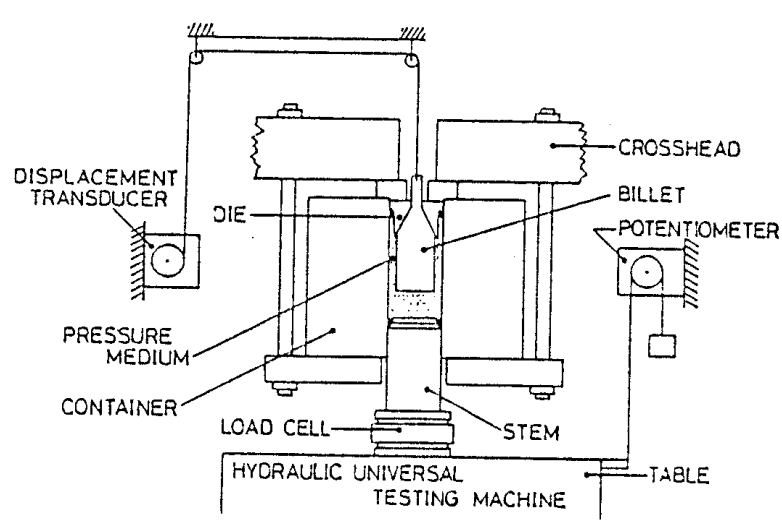

図 1 実験装置 
用いた。

$2 \cdot 2$ 压力媒体 静水圧押出しにおける圧力媒体 はステム荷重をどレットに伝達すると同時にビレッ トーダイ境界面の潤滑を行う役目を果たす必要がある. したがって夷験にはその特性（特にその粘度）を考慮 して工業用ひまし油を用いた。

$2 \cdot 3$ ダイ ダイ半角 $\alpha$ 洨変形域のひずみ速度 $\dot{\varepsilon}$ に大きな影響をおよほすすため過去の研究結果に基づき HDPEの押出加工に有効とされる $\alpha=20^{\circ}$ の円すい夕゙ イに統一した。 また出口径は各押出し比に応じて径を 決めた。

$2 \cdot 4$ ビレット ビレットは高密度ポリエチレン ((株) 三井石油化学 Hizex 5300 B $\bar{M}_{w}=1.2 \times 10^{5}$ 〕であ る.ビレット先端は押出開始までのシーとと潤滑作用 さらにダイ半角を考慮し $19^{\circ}$ のテーパノーズをつけ た。寸法は直径 $34.5 \mathrm{~mm}$ (ただし図 3 に示す実験では それぞれの圧力媒体量に応じて径を求めた), 全長 $170 \mathrm{~mm}$ また押出し比 $R$ を次式で定義する。

$$
R=\frac{A_{0}}{A_{f}}=\left(\frac{d_{0}}{d_{f}}\right)^{2}
$$

$A_{0}$ : ビレット断面積 $d_{0}$ : ビレット径

$A_{f}:$ ダイ出口断面積 $d_{f}: タ^{\prime}$ イ出口径

$2 \cdot 5$ ハイドラフィルム押出し 従来の静水圧押 出しでは荷重伝達が圧力媒体を介して行われるためそ の圧縮性によるポテンシャルエネルギーの蓄積が生じ スティックスリップなどの不安定現象が誘発される。 八イドラフィルム押出しは压力媒体量を最小限にとど めこれらの不安定現象の抑制を狙ったものでる。図 2(a)に示されるように押出開始時まではビレットを ステムが直接押込み押出開始後適当時に従来の静水圧 押出しに移行する(図 2(b))。つまりビレット周囲の 流体压を $P_{f}$, ビレット軸応力を $\sigma_{0}$ とすると押出開始 時には $\sigma_{b}>P_{f}$ であるが押出しの進行とともに圧力媒 体洨压縮され $P_{f}$ は增大し $\sigma_{b}=P_{f}$ となるとビレットー

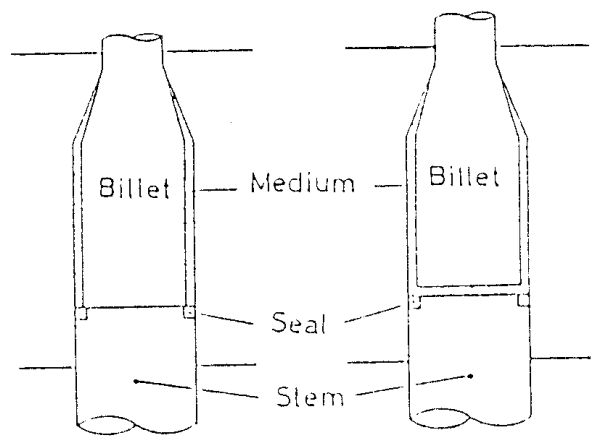

(1) Up To Bieakthrough (2) During Extrusion 図 2 ハイドラフィルム押出し
ステム間に压力媒体が入り込み従来の静水圧押出しに 遷移する。本実験では予備実験としてステム上端にス イッチを付虽しマンガニン压カゲージを用いて流体压 を測定しこの過程を検知した。

\section{3. 実験結果および考察}

\section{3・1 圧力媒体量が押出挙動におよほすす影響 八} イドラフィルム押出しでビレットーコンテナ間の半径 方向のすきまを変化させた場合，すなわち压力媒体量 を変化させた場合にそれが押出挙動におよ洛す影響を 図 3 に示す.また図3〜8では押出速度をダイ出口部に おけるひずみ速度に換算して併せて図に示す。ここで スティックスリップなどの動的不安定現象の発生洨棌 とんど押出開始時に限られる ${ }^{(2)}$. したがって不安定現 象の防止にあたっては押出開始時までは少なくともス テムが直接ビレットを押していることが必要となる。 そのため子備実験の結果よりすきまを $0.25,0.50$, $0.75,1.00 \mathrm{~mm}$ (それぞれビレット径は $34.5,34.0$, $33.5,33.0 \mathrm{~mm}$, シリンダ内径は $35.0 \mathrm{~mm}$ の四とお りに定めて実験を行った。図 3 で洨圧力変動が生じた 場合，上限值と下限值を直線で結んで示してあるが押 出速度 $0.1 \mathrm{~mm} / \mathrm{s}$ 近傍において圧力変動が生ずるケー スが多く見られた，特にすきまが広い場合には変動が 生ずる速度領域が広がり変動幅も大きくなる傾向にあ る。すきまを $0.25 \mathrm{~mm}$ (ビレット径 $34.5 \mathrm{~mm}$ )に採っ た場合，押出過程の安定度が非常に高かったため以下 の報告においてはハイドラフィルム押出しとしてビレ ット径をすべて $34.5 \mathrm{~mm}$ に統一して夷験を行った。 すなわち押出開始時のシリンダ内の圧力媒体量を全体 の約 $0.02 \%$ と定めた.

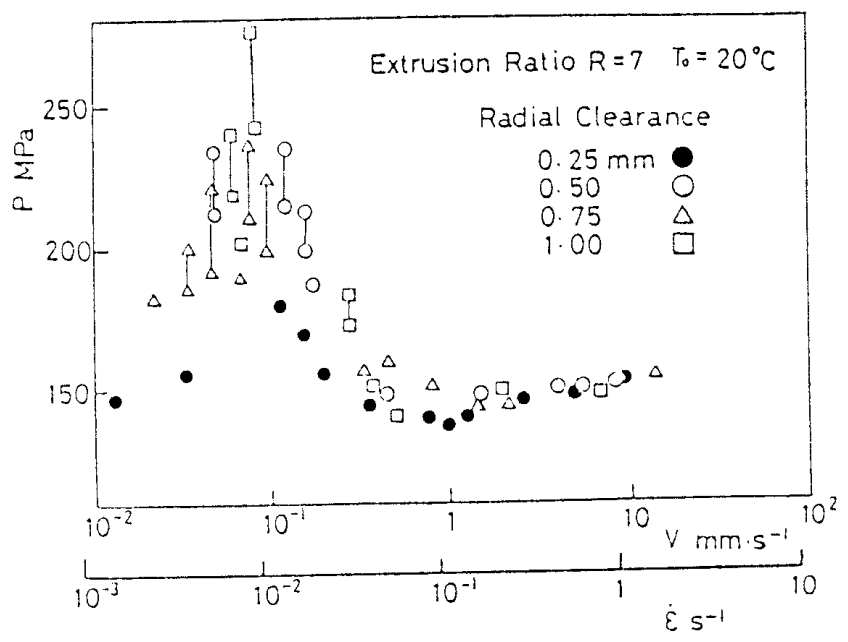

図 3 押出圧力とひずみ速度 $\dot{\varepsilon}$ の関保

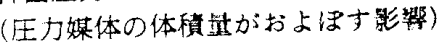


$3 \cdot 2$ ハイドラフィルム押出しの䄨出挙動(静水王押 出しとの比較）およびビレット温度上昇＼cjkstart過去の報 告より押出加工中にビレットに発生する温度上昇は HDPEの温度依存性のために押出過程に大きな影響 を与えると推測される(1).したがって本寒験ではダイ 出口部におけるビレット温度上昇の測定を熱電対を用 いて行い綐軸右側に初期設定温度より生じた上昇温度 を採り押出挙動と併せ図 4,5に示した. 図 4 に示され るとおり HDPEの静水圧押出しにおいては定常押出 し不可能となる速度領域の存在が従来より確認されて いるがハイドラフィルム押出加工の場合この速度領域 (ひずみ速度 $\dot{\varepsilon}=0.01 〜 0.2 \mathrm{~s}^{-1}$ )では押出圧力の単謂 減少は見られるがほぼ定常な押出しが可能となってい る。またひずみ速度 $0.01 \mathrm{~s}^{-1}$ 付近において極大值さら に0.1 s $\mathrm{s}^{-1}$ 付近で極小値をそれぞれ持つ.この原因と しては図 4 に示されるダイ出ロにおけるビレット温度 上昇曲線 (測定値) から明らかなように，この速度領域 における押出加工中に発生するビレット温度上昇が急 激であるためであると推測される。つまりひずみ速度 の上昇に伴いHDPEのひずみ速度依存性に起因する 押出圧力上昇の傾向が見られるはずであるがこの領域 ではビレットに急激な温度上昇が生ずるために HDPEの温度依存性が支配的となりビレットの変形 抵抗が著しく低下する。その結果ひずみ速度に対応す る押出圧力の傾きがここでは負に䎐ずる，また静水圧 押出しのみに大きな圧力変動が生ずる原因としては多 量の圧力媒体を押出加工時に使用するため押出開始直 前までに非常に大きなポテンシャルエネルギーが圧力 媒体に蓄積され押出開始值後のひずみ速度が非常に不 安定となる。その結果生ずるビレット温度上昇により 変形抵抗ならびに摩摖抵抗が不安定となり非定常な押

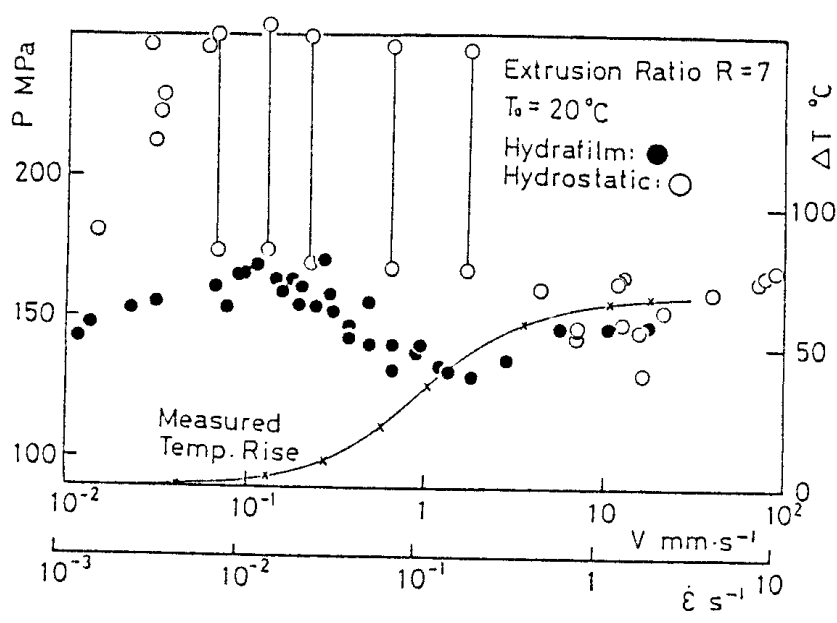

図 4 押出圧力およびビレット温度上昇に

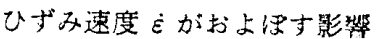

出過程一一すなおスティックスリップが誘発される と考えられる。またひずみ速度が $0.1 \mathrm{~s}^{-1}$ 以上の領域 では温度上昇はきうに続くが，その近傍を変曲点とし て温度上昇率が低下するため押出圧力は增加に転ず ろ.その結果押出過程は静水圧・ハイドラフィルム押 出しともに定常となる．しかしさらにひずみ速度の上 昇を試みた場合, $5.0 \mathrm{~s}^{-1}$ を超えると製品に螺線状の 破壊が生ずるケースが見られた。

\section{3・3 タイ・ビレットを予熱した場合の押出挙勳}

図うに押出し比 $R=7$ においてダイ・ビレットを予熱 した場合（ $\left.T_{0}=40,60,100^{\circ} \mathrm{C}\right)$ の押出圧力とひずみ（押 出）速度の関係を示す。また同時に各予熱温度てのダ イ出ロ部のビレット温度上昇も併せて示す. 図 5 より 明らかに静水圧押出しにおいては予熱温度を高めると 押出圧力の低減が可能となりさらに定常押出不可能な 速度領域の幅をせばめ変動幅も小さくすることが可能 となる.この結果は前述したビレット温度上昇が押出 学動におよほすす影響をよく説明し得る。すなわちビレ ットの温度上昇率は図に示されるとおり予熱温度の上 昇に伴い逆に低下する。その結果この領域でのひずみ 速度に対する押出圧力の傾きは，ほ平たんとなり定 常な押出しが行われると推測される。

$3 \cdot 4$ 予熱した場合の高押出し比での押出举動 図 6 8 に予熱温度を $60,100^{\circ} \mathrm{C}$ に採り押出し比 $R$ を 9,10 に上げた場合の押出圧力とひずみ速度の関保を 示す.図 6〜8より初期設定温度を上げた場合でも押出 し比を上げた場合には定常押出し可能な速度領域は限 定されるということが確認される. 図 9 に初期設定温

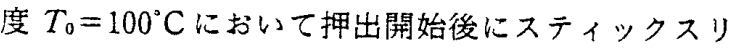
ップが発生した例を非定常, 発生しない場合を定常と

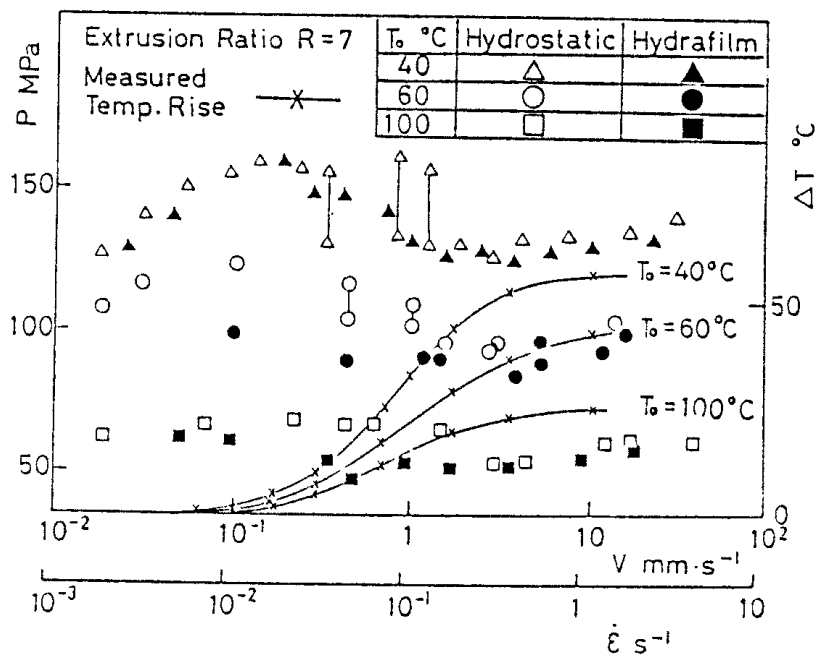

図 5 押出圧力とひずみ速度の関係（初期設定 温度 $T_{0}=40,60,100^{\circ} \mathrm{C}$ にとった場合) 


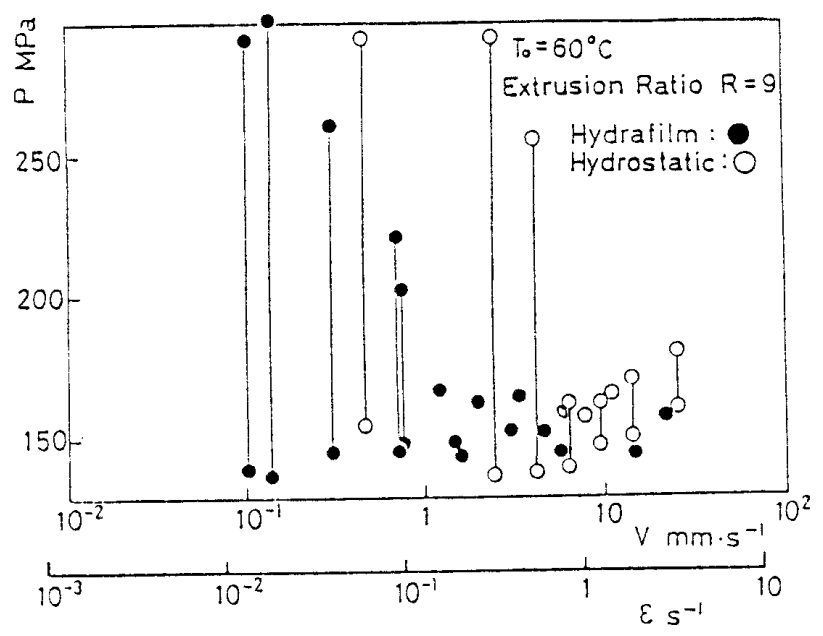

図 6 押出圧力とひずみ速度の関係

（初期設定温度 $T_{0}=60^{\circ} \mathrm{C}$, 押出し比 $R=9.0$ )

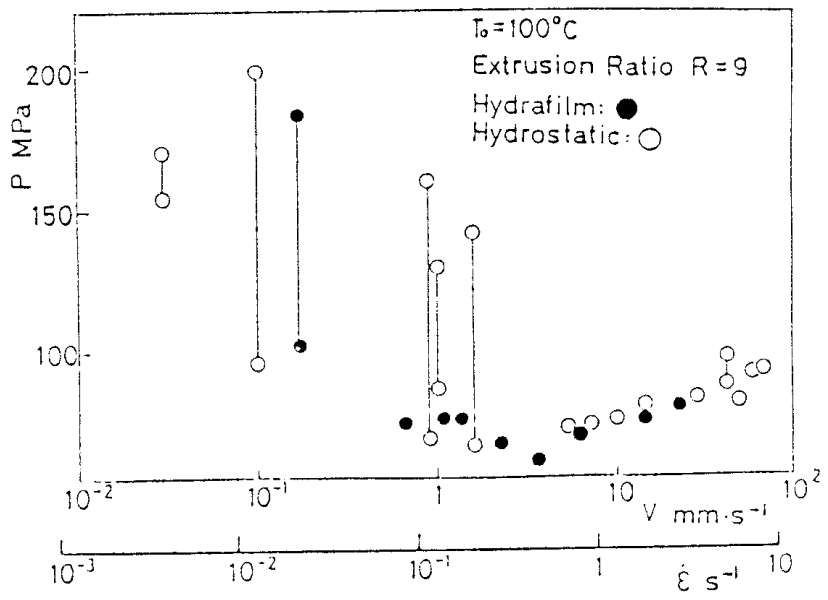

図 7 押出圧力とひずみ速度の関保

(初期設定温度 $T_{0}=100^{\circ} \mathrm{C}$, 押出し比 $R=9.0$ )

し，さらに定常押出しが可能となる速度領域を安定領 域として白色部で示す（緃軸：押出し比，横軸：押出 速度)ここては押出し比の上舁に伴い定常押出し可能 となる速度領域が非常に限定されることが顕著に示さ れている。

\section{4. 結言}

HDPEのハイドラフィルム押出過程におよぼす押 出速度, 温度上早の影曾を調べた結果, 次のようなこ とが明らかとなった。

（1）主に低ひずみ速度領域において発生する動的 不安定現象は，この領域て生ずるビレットの急激な温 度上秋に起因する。

（2）（1）を考虑したうえで压力媒体望を最小にと どめたハイドラフィルム押出加工法により高速度での

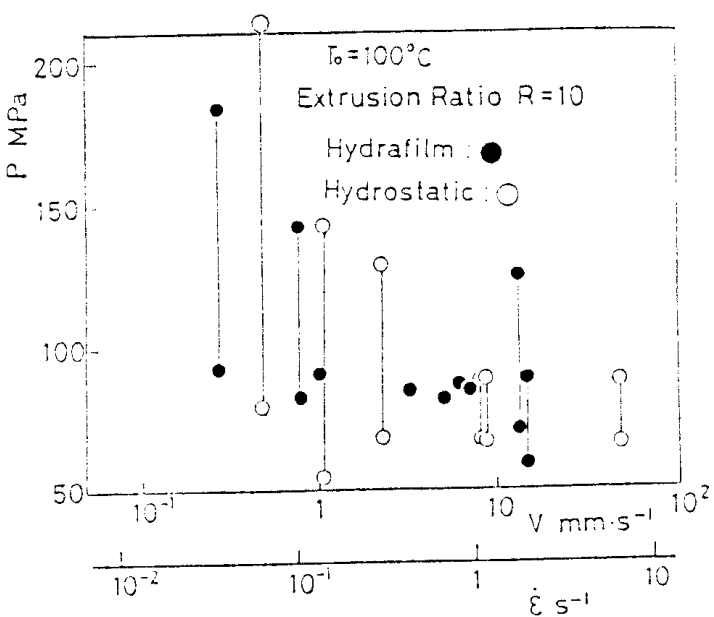

図 8 押出王力とひずみ速度の関係 (初期設定温度 $T_{0}=100^{\circ} \mathrm{C}$, 押出し比 $R=10.0$ )

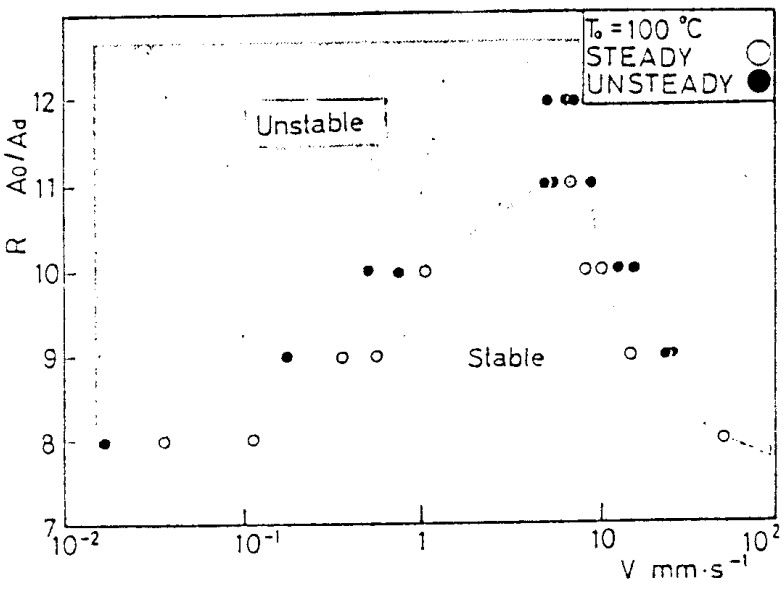

図 9 定常押出し可能となる押出速度領域（白色部）

押出しを行うかあるいは予熱温度を適当に高く採って 押出加工を行えばスティックスリップに代表される動 的不安定現象の防止あるいは最小限までの抑制が可能 となる。

(3) 高押出し比でのハイドラフィルム押出加工を 行う場合，定常押出し可能なひずみ速度領域流非常に 限定されるが，ひずみ速度・初期設定温度を適当に採 ればHDPEてい押出し比 $R=11.0$ までの定常押出し が可能である。

\section{文献}

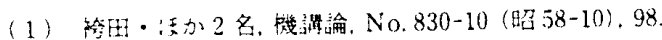

(2) Fiorentino. R. J., 估加2各. Sume Practical Considerations for Hydrostatic Extrusion, H. LI. D. Pugh (Ed.). Mechanical Engineering Publications. London. 1973. 85

(3) Coates. P. D.. 活加 2 名, J. Water. Sci, 15-10)(1980), 359 . 